\title{
GOMMENTS
}

\section{SECONDARY LIABILITY OF CONTROLLING PERSONS UNDER THE SECURITIES ACTS: TOWARD AN IMPROVED ANALYSIS}

\section{INTRODUCTION}

In the securities legislation of both 1933 and 1934, Congress included statutory provisions extending liability beyond individuals "directly" or "primarily" responsible for violations, to a "secondary" level more remote from the infraction. The legislation places vicarious responsibility for offenses upon those who "control" violators. Although analogous to traditional agency or respondeat superior doctrines, this variety of secondary liability extends beyond those common law relationships to an amorphous class of individuals or entities to which Congress gave the name "controlling persons." The evidence seems to be that a substantial degree of ambiguity was intentional on the part of the legislature in its design of these mechanisms, ${ }^{1}$ and the political climate of the era in which the provisions were conceived was supportive of a powerful and flexible legal tool to penetrate corporate formalisms. ${ }^{2}$

The flexibility embodied in these provisions of the securities acts also created the potential for judicial misapplication. This danger was particularly acute when the fluid and difficult concept of "control" was applied to business relationships. The availability of the controlling person provisions as a weapon for the enforcement of the securities laws offered courts a convenient means by which to impose liability on a "deep pocket," or seek equitable results.

1 See, e.g., text accompanying note 6 infra.

2 See generally R. DEBEDTs, THE NEw DeAL's SEC 1-85 (1964); H.R. Rep. No. $85,73 \mathrm{~d}$ Cong., 1st Sess. 2 (1933):

The background of the President's message is only too familiar to everyone. During the post-war decade some 50 billions of new securities were floated in the United States. Fully half or $\$ 25,000,000,000$ worth of securities floated during this period have been proved to be worthless. These cold figures spell tragedy in the lives of thousands of individuals who invested their life savings, accumulated after years of effort, in these worthless securities. The flotation of such a mass of essentially fraudulent securities was made possible because of the complete abandonment by many underwriters and dealers in securities of those standards of fair, honest, and prudent dealing that should be basic to the encouragement of investment in any enterprise. Alluring promises of easy wealth were freely made with little or no attempt to bring to the investor's attention those facts essential to estimating the worth of any security. High-pressure salesmanship rather than careful counsel was the rule in this most dangerous of enterprises. 
The case law in the area of controlling person liability is plagued by vague holdings, questionable statutory interpretation, and disregarded distinctions. This Comment will examine these practical problems and also will explore sources of theoretical confusion. Through a combination of statutory interpretation and case analysis, it will be argued that a new view of the controlling person provisions is necessary.

The Comment begins with an explanation of the statutory sections and major policies of the controlling person provisions. Following this background discussion, the Comment analyzes the relationship between these provisions and other vehicles of secondary liability, concluding that the statutory provisions complement the common law doctrines of agency and respondeat superior rather than pre-empt them. The Comment next proposes a two-step analytical approach to controlling persons actions. Under this approach, the appropriate analysis involves a status phase, focusing on the control relationship between the defendant and the primary violator, and a liability phase, determining whether any of the sections' exculpatory defenses apply.

Turning to existing case law, the Comment surveys a number of inconsistencies in court decisions on major issues. This analysis demonstrates that the preservation of theoretical distinctions on such issues as the scope of control required for controlling person status, the necessity for an affirmative act of inducement under the section 20(a) defense, and the directness of control required for control status, would eliminate the existing confusion on controlling person issues and improve judicial consistency. The Comment concludes by suggesting that these provisions are addressed to special instances of indirect violations of the securities acts, and urges that controlling person liability should be viewed as a subset of the general liability in section 20(b) for those who violate the law through others.

\section{The Controlling Person Statutes as a Basis for Secondary LiABILITY UNDER THE SECURITIES ACTS}

\section{A. The Statutes}

Congress initially imposed vicarious statutory liability on controlling persons in section 15 of the Securities Act of 1933. ${ }^{3}$ The section reads as follows:

Every person who, by or through stock ownership, agency, or otherwise, or who, pursuant to or in connection with an

3 Securities Act of 1933, $\$ 15,15$ U.S.C. $\$ 770$ (1970). The final qualifying clause was added in 1934 . See note 25 infra \& accompanying text. 
agreement or understanding with one or more other persons by or through stock ownership, agency, or otherwise, controls any person liable under sections $77 \mathrm{k}$ or 771 of this title, shall also be liable jointly and severally with and to the same extent as such controlled person to any person to whom such controlled person is liable, unless the controlling person had no knowledge of or reasonable ground to believe in the existence of the facts by reason of which the liability of the controlled person is alleged to exist.

Rule 405, promulgated under the 1933 Act, defined the term "control" for purposes of judicial and administrative construction:

Control. The term "control" (including the terms "controlling," "controlled by" and "under common control with") means the possession, directly or indirectly, of the power to direct or cause the direction of the management and policies of a person, whether through the ownership of voting securities, by contract, or otherwise. ${ }^{*}$

The Securities Exchange Act of 1934 also provided for controlling person liability for violations, utilizing a new set of statutory standards. Section 20(a) states:

Every person who, directly or indirectly, controls any person liable under any provision of this chapter or of any rule or regulation thereunder shall also be liable jointly and severally with and to the same extent as such controlled person to any person to whom such controlled person is liable, unless the controlling person acted in good faith and did not directly or indirectly induce the act or acts constituting the violation or cause of action. ${ }^{5}$

The concept of "control" under the 1934 provision extended potential liability to a wide range of personal and corporate relationships, as did the 1933 provision. Congress intended to allow broad and flexible application of the term, as the following excerpt from a 1934 House Report indicates:

In this section and in section 11, when reference is made to "control", the term is intended to include actual control as well as what has been called legally enforceable control. (See Handy \& Harmon v. Burnet (1931) 284 U.S. 136.) It was thought undesirable to attempt to define the term. It would be difficult if not impossible to enumerate or to anticipate the many ways in which actual control may be exerted. A few examples of the methods used are stock

5ecurities Exchange Act of 1934, $\$ 20(a), 15$ U.S.C. $\$ 78 \mathrm{t}(\mathrm{a})(1970)$. 
ownership, lease, contract, and agency. It is well known that actual control sometimes may be exerted through ownership of much less than a majority of the stock of a corporation either by the ownership of such stock alone or through such ownership in combination with other factors. ${ }^{6}$

Operating as a unit, the controlling person provisions of the 1933 and 1934 securities acts attempt to allocate liability for statutory violations in accordance with the realities of business relationships. ${ }^{7}$ Consistent with this intention, the consequences of liability do not attach because of mere structural or organizational domination: controlling persons with an apparent connection to a violation may avoid liability in particular cases on the grounds of good faith or lack of knowledge or involvement.

\section{B. The Place of the Controlling Person Provisions Among Vehicles for Secondary Liability for Violations}

Congress' decision to make controlling persons liable for violations of the securities laws parallels judicial efforts to impose secondary liability under traditional theories of agency or aiding and abetting. Because of this similarity, there has been considerable uncertainty regarding the relationship between the statutory and common law approaches. ${ }^{8}$ The debate has focused upon the extent to which the statutory provisions represent the exclusive basis for secondary liability.

Some courts have suggested that the statutes are pre-emptive, maintaining that the express language of the controlling person provisions precludes the application of common law agency standards

6 H.R. REP. No. 1383, 73d Cong., 2d Sess. 26 (1934).

7 The future of controlling person litigation seems assured: the proposed Federal Securities Code currently contains the following provision:

[Persons liable.] (a) [Controlling persons.] A person who controls a person liable under this Code (as defined in section 217A), whether that person is liable directly or by virtue of this section, is liable to the same extent as the controlled person, unless the controlling person proves (1) that he was not a controlling person at the time of any of the acts giving rise to liability, (2) that he did not know, and had no reasonable ground to believe, that the controlled person's conduct was unlawful or a breach of duty, or involved a fraudulent act, a misrepresentation, or nondisclosure of a fact of special significance (as defined in section 1303(c)) by an insider (as defined in section $1303(\mathrm{~b})$ ), or (3) in the case of section 1413 that he acted in good faith and did not induce the transactions in question; but a person who controls a person liable under or in connection with part IXC is not liable by virtue of that fact alone.

ALI FED. SEC. CODE $\$ 1419$ (a) (Tentative Draft No. 6, April 1, 1977) (brackets and parentheses in original).

8 See, e.g., Rolf v. Blyth, Eastman Dillon \& Co., Inc., 570 F.2d 38, 48 nn.17, 18 (2d Cir. 1978) (recognition of judicial disharmony on the issue, and the inherent difficulty of the question). 


\section{of liability. ${ }^{9}$ An emerging judicial ${ }^{10}$ and scholarly ${ }^{11}$ consensus, however, indicates that agency doctrines serve to complement the}

${ }^{9}$ See, e.g., Zweig v. Hearst Corp., 521 F.2d 1129, 1132-33 (9th Cir. 1975), cert. denied, 423 U.S. 1025 (1975); SEC v. Lum's, Inc., 365 F. Supp. 1046, 106163 (S.D.N.Y. 1973). It is notable, however, that a number of the decisions frequently cited as authority for the exclusivity principle fail to support the proposition. See, e.g., Rochez Bros., Inc. v. Rhoades, 527 F.2d 880 (3d Cir. 1975); Lanza v. Drexel \& Co., 479 F.2d 1277 (2d Cir. 1973); Kamen \& Co. v. Paul H. Aschkar \& Co., 382 F.2d 689 (9th Cir. 1967), cert. granted, 390 U.S. 942 (1967), cert. dismissed, 393 U.S. 801 (1968).

The Kamen decision, cited in Zweig and Lum's as controlling authority, has been misread as supporting exclusivity. The opinion initially gives the impression that the court applied the defenses of section 15 despite the existence of an agency relationship. The underlying theme of the court's analysis indicates, however, that the violation was not within the scope of the agency, making strict liability inapplicable. The buying dealer had unreasonably relied upon the agent's authority because he was on notice that the agent's representations violated exchange rules. Id. 696. The circuit court, therefore, looked to section 15 only as a potential basis for liability.

The Lanza opinion has similarly been misconstrued. Because the defendant security partner had not violated Rule $10 \mathrm{~b}-5$ or failed to fulfill his obligations, "the court did not actually reach the question of whether Drexel [the defendant] had liability either under respondeat superior ... or under the controlling persons sections ...." Note, The "Controlling Persons" Liability of Broker-Dealers for Their Employees' Federal Securities Violations, 1974 DukE L.J. 824, 838 n.81 (1974) [hereinafter cited as "Controlling Persons" Liability].

A third source of judicial misinterpretation is Rochez Bros. The court's statement that "principles of agency, i.e. respondeat superior, are inappropriate to impose secondary liability in a securities violation case," 527 F.2d at 884 , coupled with a favorable reference to the Kamen rule, imply that the statutory provisions are the exclusive basis for secondary liability. Id. 885 n.9. Nevertheless, the court addressed the plaintiff's allegation of agency liability, finding insufficient support for the claim on the facts. Id. 884. This inconsistency can be resolved, however, if it is recognized that the court was worried about the misapplication of both the strict liability standard of agency and the statutory defenses under the controlling person provisions. When viewed as a whole, it is clear that the reference to section 20 (a) as the exclusive statement of vicarious liability is addressed to the situation in which a relationship satisfies section 20 (a) control status, but not agency or employment.

10 See SEC v. Management Dynamics, Inc., 515 F.2d 801, 811-13 (2d Cir. 1975); Fey v. Walston \& Co., Inc., 493 F.2d 1036, 1051-52 (7th Cir. 1974); Johns Hopkins University v. Hutton, 422 F.2d 1124, 1130 (4th Cir. 1970), cert. denied, 416 U.S. 916 (1974); Armstrong, Jones \& Co. v. SEC, 421 F.2d 359, 361-63 (6th Cir. 1970), cert. denied, 398 U.S. 958 (1970); Plunkett v. Dominick \& Dominick, Inc., 414 F. Supp. 885, 887-89 (D. Conn. 1976). See also Sennott v. Rodman \& Renshaw, 474 F.2d 32 (7th Cir. 1973), cert. denied, 414 U.S. 926 (1973) (opinion of Douglas, J., dissenting from denial of certiorari). Justice Douglas noted: "The purpose of the Act is to expand, not restrict, the public's remedies." Id. 929. Cf. SEG v. Geon Industries, Inc., 531 F.2d 39, 54-55 (2d Cir. 1976) (appropriateness of common law agency concepts in some instances does not justify their use when it will not further the policies of the securities acts).

11 The leading commentator in this field has predicted that the controlling person statutes will come to be viewed as available only when necessary to impose liability, thus restricting access to their "special defenses." See Ruder, Multiple Defendants in Securities Law Fraud Cases: Aiding and Abetting, Conspiracy, In Pari Delicto, Indemnification, and Contribution, 120 U. PA. L. Rev. 597, 608 (1972). See also "Controlling Persons" Liability, supra note 9, at 832-38; Comment, The Controlling Persons Provisions: Conduits of Secondary Liability Under Federal Securities Law, 19 VIIL. L. REv. 621, 630-3I (1974). 
statutory provisions. Under this approach, the controlling person provisions are considered to be one of several potential vehicles for the imposition of secondary liability; their use is restricted to situations in which the common law theories of agency and aiding and abetting are untenable. Instead of serving as a vehicle for all securities prosecutions, the provisions are available to reach particular lines or methods of control otherwise inaccessible to plaintiffs.

The nonexclusivity view of the controlling person provisions was adopted by the Securities and Exchange Commission in 1967. In an amicus brief filed in Paul H. Aschkar \& Co. v. Kamen \& Co., ${ }^{12}$ the SEC argued that the controlling person provisions were inapplicable to conventional employment situations in which the law of agency ${ }^{13}$ would ordinarily impose liability upon a responsible principal:

We submit . . . that the controlling-persons provisions under which the court analyzed the federal aspect of petitioner's claim are essentially irrelevant in the ordinary employer-employee context, as exists in this case. These provisions were designed to reach situations in which there are technical legal barriers between the persons in fact responsible for violations of the securities acts and those injured by the violations. . . . [T] he controllingpersons provisions were designed to avoid those barriers by, for example, piercing the corporate veil to reach controlling stockholders. They were intended to enlarge, not restrict, the scope of vicarious liability otherwise arising under the securities acts. Hence, the exceptions set forth in those provisions are applicable only when it is necessary to invoke these expanded premises of liability. Conversely, they are not applicable here because respondents' liability may be and should be determined directly under the antifraud provisions themselves. ${ }^{14}$

Despite general recognition that the controlling person provisions are essentially fashioned for use in situations where the facts pose a barrier to traditional approaches, the statutory provisions

12390 U.S. 942 (1968).

13 See Restatement (Second) of Agency $\$ 257$ (1958): “A principal is subject to liability for loss caused to another by the other's reliance upon a tortious representation of a servant or other agent, if the representation is: (a) authorized; (b) apparently authorized; or (c) within the power of the agent to make for the principal."

14 Brief for SEC as amicus curiae, Paul $\mathrm{H}$. Aschkar \& Co. v. Kamen \& Co., 390 U.S. 942 , cert. dismissed, 393 U.S. 801 (1968), quoted in Ruder, supra note 11 , at 607 . 
have repeatedly been used to reach classic employment relationships. ${ }^{15}$ Moreover, the potential sufficiency of section 20(b) of the 1934 Act as a vehicle to serve the rule of respondeat superior has apparently been ignored. That subsection states: "It shall be unlawful for any person, directly or indirectly, to do any act or thing which it would be unlawful for such person to do under the provisions of this title or any rule or regulation thereunder through or by means of any other person." 16 This failure to apply the principle of nonexclusivity in practice has significantly affected the disposition of securities actions in two ways. First, the special defenses of the controlling person provisions have been made potentially available to defendants when strict agency-based liability should be applied. Second, the case law involving control relationships has been flawed and distorted because of the misapplication of the statutory provisions. As will be discussed, ${ }^{17}$ both of these developments have obscured the intended congressional rationale for controlling person liability in general.

\section{The Two-Step Analytical Model: Status and Liability}

The primary cause of analytical disorder in this area of securities law is the persistent confusion of the two distinct conditions required for a finding of controlling person liability: (1) that the defendant is a controlling person in relation to the primary violator, and (2) that none of the special defenses supplied by the statutory provisions apply to the facts of the case. These elements will be referred to as the status issue and the liability issue, respectively.

\section{A. Status}

In the status phase of controlling person analysis, the inquiry focuses upon the potential for the exercise of control or influence. Proof of the actual use of this control is not required to establish secondary liability under the provisions. Instead, the illegal exercise of control is presumed when the exculpatory language is not shown to apply to the transaction in question.

As suggested by the statutory language and its supporting regulations and legislative history, ${ }^{18}$ the concept of "control" underlying

15 See, e.g., Zweig v. Hearst Corp., 521 F.2d 1129 (9th Cir.), cert. denied, 423 U.S. 1025 (1975) (publisher-employer held to be controlling person as to author of financial column). See also cases discussed in note 33 infra.

16 Securities Exchange Act of 1934, $\$ 20$ (b), 15 U.S.C. $\$ 78 t(b)(1970)$.

17 See text following note 94 infra.

18 See text accompanying notes 2-6 supra. 
this form of derivative liability is vaguely defined, and apparently includes every conceivable mechanism or relationship capable of serving as a conduit for control. Where the violator is a corporate entity, the statutory language contemplates that the ownership of a controlling equity interest may give rise to a control relationship. ${ }^{19}$ Similarly, status as a director of a corporation has consistently been held to involve the opportunity for "control" within the meaning of the statutes. ${ }^{20}$ In these two contexts the "controlling person" is presumably on notice and fully aware of his general status under the securities laws. More troubling, however, are those situations in which an individual or group is unexpectedly found to "control" a violator. For example, creditors of a business enterprise may effectively control the entity's transactions in certain circumstances, and thus might be held liable as controlling persons. ${ }^{21}$

The potential for a myriad of factual patterns involving control relationships precludes attempts meaningfully to catalogue or analyze the breadth of the controlling person provisions, as some commentators ${ }^{22}$ and courts have noted. In Klapmeier $v$. Telecheck International, Inc. ${ }^{23}$ the court explained the ambiguity and interpretative problems of the status issue:

The issue of "control" is a complex fact question which requires an examination of the relationships of the various alleged "controlling persons" to the person or entity which transacted the sale of securities alleged to have violated the Act, an examination of which cannot be limited to a cursory review of their proportionate equity positions, employment or director status on the relevant dates. While a majority shareholder might as a matter of law be held to "control" the entity regardless of his actual participation in management decisions and the specific transaction in question, the absence of a substantial owner(1966).

19 See, e.g., Sommer, Who's "In Control"?-SEC, 21 Bus. LAw. 559, 563

20 See, e.g., Rochez Bros., Inc. v. Rhoades, 527 F.2d 880 (3d Cir. 1975); Moerman v. Zipco, Inc., 302 F. Supp. 439, 447 (E.D.N.Y. 1969), aff'd per curiam, 422 F.2d 871 ( $2 \mathrm{~d}$ Cir. 1970). One court has even suggested that director status is an essential element for controlling person status. Holloway v. Howerdd, 377 F. Supp. 754,761 (M.D. Tenn. 1973), aff'd in part, rev'd in part on other grounds, 536 F.2d 690 (6th Cir. 1976).

21 See, e.g., Douglas-Hamilton, Creditor Liabilities Resulting from Improper Interference with the Management of a Financially Troubled Debtor, 31 Bus. LAw. 343 (1975).

22 See Sommer, supra note 19, at 559-83. See also Enstam \& Kamen, Control and the Institutional Investor, 23 Bus. LAw. 289, 319-20 (1968).

23315 F. Supp. 1360 (D. Minn. 1970). 
ship of shares does not foreclose liability under the Act as a "controlling person." 24

Although this commentary recognizes the subtleties involved in determining controlling person status and suggests the characteristics of an insufficient judicial inquiry, it fails to articulate specific criteria for resolving the status issue in particular cases. The factual nature of the status issue has effectively prevented the development of universal standards.

\section{B. Liability}

The second phase of an action based upon the controlling person provisions focuses upon the exculpatory clauses in the legislation. The exculpatory language in section 15 of the 1933 Act, supplied by a special amendment in the 1934 Act, ${ }^{25}$ shields a "controlling person" from liability where he or she "had no knowledge of or reasonable grounds to believe in the existence of the facts by reason of which the liability of the controlled person is alleged to exist." 28 The effect of this language is to require awareness of the violation as a precondition to a finding of vicarious liability, except where ignorance is due to a failure to carry out a reasonable duty of inquiry.

Depending upon the identity of the alleged controlling person, this liability standard operates to penalize a supervisory lapse, but it does not impose an affirmative duty to supervise where none otherwise exists. The "reasonable grounds to believe" language may, however, create a duty to inquire when the controlling person actually receives evidence of a violation. This concept is distinguishable from the general notion of "constructive knowledge," under which information may be imputed to a person possessing no substantive knowledge of the matter whatever. ${ }^{27}$

The defenses available under the 1934 Act provision provide a broader avenue of escape for the controlling person. A "controlling

24 Id. 1361.

25 Act of June 6, 1934, ch. 404, $\$ 208,48$ Stat. 908 (amending Securities Act of 1933 , ch. $38, \S 15,48$ Stat. 84$)$.

26 Securities Act of 1933, \$15, 15 U.S.C. $\$ 770$ (1970).

27 The distinction between what may be called "actual possession" of reasonable grounds to believe on the one hand, and an affirmative duty to investigate on the other, is made elsewhere in the Securities Act. Compare Securities Act of 1933, $\$ \$ 11(\mathrm{~b})(3)(\mathrm{A}) \&(\mathrm{~B}), 15$ U.S.C. $\$ \$ 77 \mathrm{k}(\mathrm{b})(3)(\mathrm{A})$ \& (B) (1970) ("had, after reasonable investigation, reasonable ground to believe and did believe") (emphasis supplied), with Securities Act of $1933, \$ \S 11$ (b)(3)(C) \& (D), 15 U.S.C. $\$ \$ 77 \mathrm{k}$ (b) (3)(C) \& (D) (1970) ("had no reasonable ground to believe and did not believe"). 
person" is protected therein if he "acted in good faith and did not directly or indirectly induce the act or acts constituting the violation or cause of action." 28 The meaning of "good faith" in this context is arguably analogous to the standard embodied in the 1933 Act exculpatory clause. The term shields a controlling person in the absence of actual knowledge of a violation, but it also provides a defense when the controlling person should know of the violation but does not, at least when such ignorance is not due to an intentional failure to investigate.

The second element of the section 20(a) exculpatory test-the requirement that the alleged controlling person must not have directly or indirectly "induced" the violation-is difficult to construe. Moreover, the rationale supporting the addition of this standard to the good faith element is open to question. One reasonable interpretation of this clause is that the language is addressed to two special situations: (1) transactions in which a controlling person affirmatively acts to cause a violation without knowledge that the act would constitute an offense, and (2) circumstances in which a controlling person acts in good faith but fails to carry out a duty of inquiry of which he was unaware, where such failure directly or indirectly causes the offense. In these instances the statutes imposes legal responsibility despite "good faith," because ignorance of the law is an insufficient justification.

The important practical question, however, relates to the degree of action required to support a finding of direct or indirect "inducement." If a board of directors hires a managing official who subsequently violates the securities laws, is their act an indirect inducement of the offense? More fundamentally, does the term "inducement" strictly require an affirmative act? Is a controlling person's failure to provide adequate supervision actionable as a direct or indirect inducement of a violation? The case law on this point is divided, and depends heavily on the facts of each action, but it is clear that some courts do not consider affirmative causal actions essential for the imposition of vicarious liability. ${ }^{29}$

The language and statutory standards of liability of these provisions demonstrate that controlling persons are a special class under the securities laws, subject to substantial scrutiny. If an accused individual occupies a control position in relation to the primary

28 Securities Exchange Act of $1934, \$ 20$ (a), 15 U.S.C. $\$ 78 t(a)$ (1970).

29 See, e.g., discussion of Myzel v. Fields, 386 F.2d 718 (8th Cir. 1967), cert. denied, 390 U.S. 951 (1968), and subsequent cases in text accompanying notes 62-67 infra. For a criticism of these holdings as being based upon erroneous application of the controlling person provisions in agency situations, see text accompanying notes 68-72 infra. 
violator and is unable to demonstrate the applicability of the exculpatory clauses, the courts will impose statutory liability, exposing the accused to adverse financial consequences and damage to personal reputation.

\section{The Case Law: Distinctions Lost}

As previously noted, ${ }^{30}$ a theoretical understanding of the controlling person provisions has been hampered by questionable judicial interpretation. This section will survey several existing problems in the area of secondary liability in order to identify important distinctions disregarded by the courts and provide a basis for suggesting a new perception and rationale for the controlling person provisions. The problems discussed include: (1) the unspecified scope of the control required for the imposition of controlling person status, (2) the finding of "inducement" under the 1934 Act in the absence of a clear affirmative act, (3) the misreading of the opinion in Myzel $v$. Fields, ${ }^{31}$ and the use of its language to extend controlling person status to tenuous relationships, and (4) the confusing nature of the case law in this area, as exemplified by the opinion in Stern v. American Bankshares Corp..$^{32}$

\section{A. The Status Issue: Scope of Control Required}

An understanding of the status phase of controlling person analysis necessitates specification of the types of control relationships subject to the provisions. The provisions clearly require control of the violator, but the extent or comprehensiveness of the necessary control may vary.

Assuming that every "violator" is a natural person, three possible standards of controlling person status can be formulated. The first possible status test would require the alleged controlling person to have the potential for control of the violator in all phases of the violator's business activities, as is the case in many of the agency-type situations handled under the controlling person provisions. ${ }^{33}$ The

30 See text accompanying notes 15-17 supra.

31386 F.2d 718 (8th Cir. 1967), cert. denied, 390 U.S. 951 (1968).

32429 F. Supp. 818 (E.D. Wis. 1977).

33 See, e.g., Richardson v. MacArthur, 451 F.2d 35 (10th Cir. 1971) (corporation held to be a controlling person, sharing liability for violations committed by persons it hired to organize business in another state, because it had the "influence to control, direct or discipline" those persons "with regard to those dealings." Id. 42). See also SEC v. First Securities Co. of Chicago, 463 F.2d 981 ( 7 th Cir.), cert. denied sub nom. McKy v. Hochfelder, 409 U.S. 880 (1972); Hecht v. Harris, Upham \& Co., 283 F. Supp. 417 (N.D. Cal.), modified on other grounds, 430 F.2d 1202 (9th Cir. 1968). 
second possible status test would demand a showing of potential control over the violator only in the types of business activities that are capable of producing a violation such as the one at issue. The third possible status requirement would be satisfied by a demonstration of the potential for control over the violator in the specific transaction or transactions underlying the allegation of primary liability.

The required scope of control over the violator is equally unclear in situations involving a violator who is the agent of a business entity. Under these circumstances, the business entity theoretically becomes a primary violator as well, focusing the status inquiry upon persons exercising control over the business entity. If the scrutinized individuals potentially control the entity's entire business activity via conventional methods such as director status or "controlling" equity interests, the inquiry is easily resolved. A showing of personal ownership of controlling equity interests may be treated as virtually conclusive evidence of control over the entity in which the beneficial interest is held. ${ }^{34}$ Similarly, director status is considered a strong indication of the potential for control and influence, although it is not sufficient in itself to demonstrate controlling person status. ${ }^{35}$ Rules of this type are not always, however, available to the courts. Instead, the courts are often faced with individuals possessing varying degress of control over the business entity. This raises three questions: (1) Is full "entity control"-in the sense that a majority shareholder controls a corporation-required in order to demonstrate controlling person status? (2) Is control of an entity's securities issues sufficient? and (3) Is the potential for control over the particular transactions giving rise to the violation sufficient?

These fundamental questions have not been convincingly answered by the case law. Opinions vacillate as to the comprehensiveness of the potential control required by an appropriate status test. In the absence of a clear judicial exposition, an attempt to deduce or infer guiding principles must focus upon results reached in

34 See, e.g., language quoted in text accompanying note 24 supra, from Klapmeier v. Telecheck Int'l, Inc., 315 F. Supp. 1360 (D. Minn. 1970). See also Rochez Bros., Inc. v. Rhoades, 527 F.2d 880 (3d Cir. 1975); Sommer, supra note 19 , at 562-76. This conclusion seems required by the statutory language.

35 See, e.g., Stadia Oil \& Uranium Co. v. Wheelis, 251 F.2d 269, 275-76 (10th Cir. 1957). But see Moerman v. Zipco, Inc., 302 F. Supp. 439 (E.D.N.Y. 1969), aff'd per curiam, 422 F.2d 871 (2d Cir. 1970) (directors ipso facto controlling persons). Cf. Holloway v. Howerdd, 377 F. Supp. 754, 761 (M.D. Tenn. 1973), aff'd in part, rev'd in part on other grounds, 536 F.2d 690 (6th Cir. 1976) (person charged with control must occupy, at a minimum, a director's position at times material to the litigation and actively participate in the corporation's operation). 
particular fact situations. In Hawkins v. Merrill, Lynch, Pierce, Fenner \& Beane, ${ }^{36}$ the court found a control relationship in the absence of structural control or influence. The violator was technically not an employee of the brokerage firm; instead, he was a "correspondent" or "wire connection" who made arrangements for transactions subsequently executed by the firm. Merrill Lynch supplied this "correspondent" with office space as well as supplies and services of various kinds. In addition, the court noted, the firm assumed the responsibility of confirming that transactions arranged through correspondents were carried out in accordance with applicable securities rules and regulations. ${ }^{37}$

Despite the traditional employment characteristics of this relationship and the absence of a discernible control structure, the court held that Merrill Lynch was a controlling person in relation to the violations of the correspondent. This result, however, does not support the proposition that "affiliates" are generally liable for offenses committed by those with whom they deal. Merrill Lynch's scope of control was sufficient, in this case because the partnership's pattern of supervision gave it potential control over the violator in certain types of business activities capable of producing a violation. Moreover, the firm's control over its correspondent's accounts provided it with the ability to influence the violator's conduct and prevent fraud in this particular case. Merrill Lynch could have forestalled the violative transaction by closing the correspondent's omnibus account ${ }^{38}$ which allowed him to place orders for undisclosed customers and convert their funds.

Another example of judicial willingness to extend control status to a relationship in which the controlling person had less than full entity control was the decision in DeMarco $v$. Edens. ${ }^{39}$ In this case, the lower court held that a control relationship was created because the issuer influenced the best efforts underwriter via selection of that underwriter and control over the terms of the offering. ${ }^{40}$ The affrming opinion, however, substantially undercut this result. After noting that the defendant was shielded from liability under the exculpatory clauses of sections 12 and 15 of the 1933 Act, the Second Circuit commented in dictum that "[w]e harbor serious doubts

3685 F. Supp. 104 (W.D. Ark. 1949).

37 Id. $110-20$.

38 Id. $122-24$.

39 [1966-1967 Transfer Binder] FED. SEC. L. Rep. (CCH) $\llbracket 91,856$ (S.D.N.Y. 1966), aff'd, 390 F.2d 836 (2d Cir. 1968).

40 Id. 95,934. See also discussion of this case by Professor Loss at 6 Loss, Securtrues Regulatron 3931 (2d ed. Supp. 1969). 
about the district court's conclusion that appellees were . . . 'controlling persons' within the meaning of the statute." 41

One recent case, Ferland $v$. Orange Groves of Florida, Inc. ${ }^{42}$ may reinforce the notion that the status requirement may be satisfied by a showing of potential control over certain portions of the entity's business activities, or over only the transaction in question. In Ferland the court found that three corporations under the common control and direction of a single group of individuals ${ }^{43} \mathrm{had}$ made material misrepresentations concerning the investment potential of certain orange groves. ${ }^{44}$ Examining five potentially liable defendants, the court excluded two from the controlling person class and found controlling person status in the cases of three others. ${ }^{45}$ The court reasoned that two of the defendants lacked "the ability, in fact or in law, to control the activities of the Selling Corporations in relation to the latter's own customers." 46 In contrast, the court found the three other defendants to be controlling persons because they "had the ability and the right to control the liability producing activities of the Selling Corporations." 47 This second standard may represent judicial acceptance of something less than entity control, depending upon how the language is read. The phrase "the liability producing activities" may mean either of two things. It could be that the crucial factor in the court's analysis of the status issue, as in a strict "transaction control" approach, is control over those activities which produced the violation in question. A second plausible interpretation is that the three defendants were controlling persons because of their "ability and right" to control all of the potentially liability-producing activities of the corporate entity.

The Ferland opinion contains another observation germane to the determination of controlling person status, although it also relates to the liability issue. In a statement possibly addressed to the principles of vicarious liability in general, the court commented that

[f]or purposes of attaching liability under either [controlling person] provision in a manner consistent with due process, the person sought to be held liable for the conduct of another must be shown to have had the lawful authority

41390 F.2d 836, 841 (footnote omitted). The appellate opinion specifically noted that it did not reach the status issue. Id.

42377 F. Supp. 690 (M.D. Fla. 1974).

43 Id. 693.

44 Id. 701-02.

45 Id. 707.

$46 I d$.

47 Id. 
to control or influence that conduct in such a way as to have been able to avoid liability. ${ }^{48}$

This language is apparently intended to state a condition necessary, but not conclusive, for the finding of controlling person status. Moreover, it suggests that the inability of an alleged controlling person to exercise transaction control precludes such status.

This discussion of the scope of control illustrates the varying standards applied to the status issue by the courts. Although designations of controlling person status often include a finding of complete control over the individual violator or corporate entity, it is unclear at this point whether such entity control is a strict requirement. The difficulty of this question has been compounded by the reluctance of most courts to address the status issue either distinctly or comprehensively.

\section{B. The Liability Issue: "Inducement" Under the Exchange Act Provision}

The "inducement" language within the exculpatory clauses of the 1934 Act is a continual source of concern in controlling person cases. Its interpretation is critical to the determination of the boundaries of liability under the Act. ${ }^{49}$ If the term "inducement" is given a broad interpretation by the courts, some controlling persons would theoretically be unable to avoid liability despite justifiable ignorance or lack of involvement in a violation, a result which is not supported by the policy or the legislative history of the securities acts. Congress explicitly expressed the intention to impose affirmative duties in other sections of the acts; ${ }^{50}$ it could have done the same in this case by limiting the exculpatory clause of section 20 to situations in which the defendant had reasonable grounds to believe that there was no illegal conduct, or fulfilled a reasonable duty of supervision or investigation.

An examination of the case law indicates that there is no consensus regarding the necessity of an affirmative act to satisfy the inducement language. One line of cases clearly requires an affirmative act or personal involvement as a precondition to vicarious lia-

48 Id., citing Strong v. France, 474 F.2d 747 (9th Cir. 1973).

49 The "reasonable grounds to believe" language of section 15 of the 1933 Act and the "good faith" language of section 20(a) of the 1934 Act are also crucial to the interpretation of the securities acts. The survey of the exculpatory clauses will focus on the "inducement" language because the other two clauses are such complete questions of fact as to preclude effective theoretical analysis.

50 See, e.g., Securities Act of 1933, $\$ 11,15$ U.S.C. $\$ 77 \mathrm{k}$ (1976). 
bility. In Lanza v. Drexel \& Co. ${ }^{51}$ the Second Circuit viewed section 20 as a reflection of Congress' intent to impose liability only upon those controlling persons "who are in some meaningful sense culpable participants in the fraud perpetrated by controlled persons." 52 This formulation was again applied by that court in Gordon $v$. $B u r r,{ }^{53}$ and apparently was followed by the Third Circuit in Rochez Bros., Inc. v. Rhoades. ${ }^{54}$ In Rochez Bros., the court commented that " $[t]$ he legislative history of Section 20(a) illustrates that Con-. gress intended liability to be based on something besides control. That something is culpable participation." ${ }^{55}$ The opinion also stated that liability may be based on inaction only when the failure to act "intentionally furthered the fraud or prevented its discovery." 56

The Ninth Circuit in Zweig v. Hearst Corp. ${ }^{57}$ agreed that "inducement" was associated with active involvement in the events giving rise to a violation. The court held that a controlling person must show that he or she "did not directly or indirectly participate in the wrongful acts" in order to fall within the exculpatory clause. ${ }^{58}$ The opinion stressed, however, that a publisher identified as the controlling person should not be held to a standard of care as high as that of a broker-dealer.59 A test "amounting more nearly to culpability" was, therefore, appropriate. ${ }^{60}$ Using this distinction, less of an affirmative act, if any at all, would be required for the establishment of liability in the case of one accustomed to dealing in the securities markets on a regular basis.

Other courts are willing to find vicarious liability in the absence of affirmative acts or culpable involvement in the violation. The standard applied in these cases is analogous to the strict liability approach to secondary liability found in common law agency cases, and may be based on the view that the minimum requirements of

51479 F.2d 1277 (2d Cir. 1973) (en banc).

52 Id. 1299 (emphasis added).

53506 F.2d 1080, 1085 (2d Cir. 1974).

54527 F.2d 880 (3d Cir. 1975).

55 Id. 884-85.

56 Id. 890 (emphasis added).

57521 F.2d 1129 (9th Cir. 1975), cert. denied, 423 U.S. 1025 (1975).

$58 \mathrm{Id}$. 1132 (emphasis added). The Seventh Circuit may concur in this view. See Sennott v. Rodman \& Renshaw, 474 F.2d 32, 39-40 (7th Cir.), cert. denied, 414 U.S. 926 (1973), in which the court refused to find liability based on transactions carried out by a former associate of a brokerage house because of a lack of sufficient "involvement."

59521 F.2d at 1135.

$60 \mathrm{Id}$. 
due process ${ }^{61}$ should be the sole restraints in attaching vicarious liability. One important example of this interpretation of inducement is the Eighth Circuit's decision in Myzel $v$. Fields. ${ }^{62}$ The Myzel court stated that the 1934 controlling person statute "is remedial and is to be construed liberally. It has been interpreted as requiring only some indirect means of discipline or influence short of actual direction to hold a 'controlling person' liable." 63 As will be noted, ${ }^{64}$ the sentence reproduced here has frequently been misread as support for a loose interpretation of controlling person status. A careful in-context analysis of the passage indicates, however, that the Eighth Circuit was addressing the liability issue rather than the question of status. ${ }^{65}$ The court indicated through this statement that once controlling person status is established, the showing of an indirect means of discipline or influence at the time of the violation is sufficient for the imposition of liability.

In Carr v. New York Stock Exchange, ${ }^{66}$ the court suggested that section 20 liability does not require an affrmative act. Rejecting a claim that a national securities exchange is a controlling person as to member firms, the Carr court noted that as a controlling person the exchange would theoretically be liable whether it "took positive actions in furtherance of a fraudulent scheme, or merely failed to prevent a fraudulent scheme on the part of its member firms. Under $\$ 20$ (a) mere good faith or lack of knowledge of the scheme is not enough to avoid liability."

The concept of inducement accepted by the Myzel and Carr courts has been utilized to impose liability in two cases: Hawkins $v$. Merrill, Lynch, Pierce, Fenner of Beane, ${ }^{68}$ and Lorenz v. Watson. ${ }^{69}$ Both of these cases, however, are questionable authority for the general use of a loose inducement standard for two reasons: (1) the alleged controlling persons were brokerage houses with an established duty to supervise their employees, apart from any special responsibilities created by the controlling person provisions (in Lorenz the brokerage house was held liable for its salesman's "churning" because its failure to take precautionary steps to supervise its

01 See, e.g., text accompanying note 48 supra.

62386 F.2d 718 (8th Cir. 1967), cert. denied, 390 U.S. 951 (1968).

63 Id. 738 (citations omitted).

64 See text accompanying notes 73-87 infra.

65386 F.2d at 738-39.

66414 F. Supp. 1292 (N.D. Cal. 1976).

67 Id. 1303.

6885 F. Supp. 104 (W.D. Ark. 1949).

69258 F. Supp. 724 (E.D. Pa. 1966). 
employees was regarded as participation in the violation; ${ }^{70}$ similarly, the Hawkins court imposed liability because Merrill Lynch had tolerated a distinctive account arrangement with the potential for abuse ${ }^{71}$ ); and (2) the clear agency setting of the cases may undermine their authority on this point in light of the nonexclusivity argument ${ }^{72}$ that the controlling person provisions are inappropriate in such circumstances.

\section{The Myzel Formulation: Source of Continuing Confusion}

The Eighth Circuit's comment in Myzel v. Fields ${ }^{73}$ regarding the scope and interpretation of the controlling person provision in the 1934 Act has become a benchmark to which the courts have frequently reverted. Its repetition here is worthwhile for purposes of comparison. "The [1934] statute is remedial and is to be construed liberally. It has been interpreted as requiring only some indirect means of discipline or influence short of actual direction to hold a 'controlling person' liable." 74 As the preceding analysis has suggested, ${ }^{75}$ the accuracy of the second sentence as a proposition of law is questionable, at least when the controlling person provisions are removed from the agency context. Even if its accuracy were clear, however, the Myzel court's analysis of the question of liability has been substantially compromised by subsequent misinterpretations in opinions attempting to apply this language as a test for controlling person status. ${ }^{76}$

In Harriman v. E.I. duPont De Nemours of Co.,77 the Myzel language was misquoted, the court's opinion omitting the final phrase of the second sentence without indication of its removal: "The statute is remedial and is to be construed liberally. It has been interpreted as requiring only some indirect means of discipline or influence short of actual direction." 78 Using this formulation, the Harriman court read the language as a loose standard for controlling person status. If this approach were universally adopted,

70 Id. 733.

71 See text accompanying notes 36-38 supra.

72 See text accompanying notes $12-17$ supra.

73386 F.2d 718 ( 8 th Cir. 1967).

74 Id. 738 (citations omitted). For a discussion of the omitted citations, see text accompanying notes 68-72 supra.

75 See text accompanying notes $61-72$ supra.

76 The misinterpretation of the Myzel inducement language has previously been recognized. See Comment, supra note 11, at $634 \mathrm{n} .73,637 \mathrm{n} .83$ (criticism of the Anderson and Richardson courts' use of the language as a test of control).

77372 F. Supp. 101 (D. Del. 1974).

78 Id. 105 (citations omitted). 
control relationships could be found in an endless array of circumstances without regard to the reasonable expectations of the alleged controlling person.

Unfortunately, Harriman is not the only example of misuse of the Myzel statement. In Moerman v. Zipco, Inc. ${ }^{79}$ the court, in the course of declaring directors to be ipso facto controlling persons, referred to "the liberal construction of this section as including 'indirect means of discipline or influence short of actual direction," citing Myzel. ${ }^{80}$ In Anderson v. Francis I. duPont \& Co., ${ }^{81}$ the court found that two brokerage houses had the potential for control of a commodities dealer by using this quotation to support "a broad construction of the term 'controlling persons.'" 82 Similarly, the court in Richardson v. MacArthur ${ }^{83}$ erroneously applied the Myzel language as a test for status. Because "it cannot now be claimed that Bonneville lacked the influence to control, direct, or discipline MacArthur with regard to those dealings," 84 the court held that controlling person status had been established. ${ }^{85}$

Perhaps the clearest misreading of the Myzel approach is evidenced in McGraw v. Matthaei. ${ }^{86}$ There the court commented:

It is true that in order to establish control within the meaning of $\S 20(a)$, it is not necessary to establish a strict agency relationship. Rather, it is only necessary to show some indirect means of discipline or influence to find that a person is a controlling person within the meaning of the Section. ${ }^{87}$

Even though the McGraw court did not hesitate to reject the tenuous allegation of control presented by the defendant's counterclaim, the recurrent misreading and adoption of the Myzel language as a test for controlling person status is a serious problem for two reasons: (1) judicial interpretation of this type only complicates the confused case law applying the controlling person provisions, and (2) the stakes are extremely high in terms of dollars and reputation for the individual or entity mistakenly found to be a controlling person. 1970).

${ }^{79} 302$ F. Supp. 439 (E.D.N.Y. 1969), aff'd per curiam, 422 F.2d 871 (2d Cir.

80302 F. Supp. at 447.

81291 F. Supp. 705 (D. Minn. 1968).

82 Id. 710.

83451 F.2d 35 (10th Cir. 1971).

84 Id. 42 (footnote omitted).

$85 \mathrm{Id}$.

86388 F. Supp. 84 (E.D. Mich. 1972).

87 Id. 93 (citing Myzel). 
Nevertheless, careful scrutiny and discussion of this issue in forthcoming opinions can easily remedy the error.

\section{Stern v. American Bankshares Corp.: A Distress Signal}

A recent case in which a court was asked to rule upon the sufficiency of a complaint under the controlling person provisions exemplifies the potential for confusion in this area of the law. In Stern v. American Bankshares Corp. ${ }^{88}$ the court was unreasonably imprecise in its analysis of the standards to be applied in determining the sufficiency of a complaint or in ruling on the merits of an action. First, the Stern court stated that a complaint need not allege the exercise of control over the transaction giving rise to the violation. ${ }^{39}$ This proposition was supported with quotations from the opinion in Holloway $v$. Howerdd:

The court accepts as settled law the proposition that directors of a corporation may be found liable as controlling persons, both under the Securities Act and the Exchange Act, even without actively participating in the conduct upon which liability is founded. (Gitations omitted)

Nevertheless, a director's liability, pretermitting the good faith defense of $\S 78 \mathrm{t}$, presupposes some extent of actual participation in the corporation's operation before the consequences of control may be imposed..$^{90}$

The use of the Holloway language was improper, because that language had been addressed to a liability issue rather than to a status question. In addition to the explicit use of the word "liability," note the reference to "the consequences of control" rather than the fact of control itself. Moreover, the standards used in cases involving the liability of a director alleged to be a controlling person are poor precedent for determining the liability of individuals lacking director status.

88429 F. Supp. 818 (E.D. Wis. 1977).

$89 \mathrm{Id} .823$.

90429 F. Supp. at 823-24 (quoting Holloway v. Howerdd, 377 F. Supp. 754, 761 (M.D. Tenn. 1973), aff'd in part, rev'd in part on other grounds, 536 F.2d 690 (6th Cir. 1976). The authority used by the Holloway court was Moerman v. Zipco, Inc., 302 F. Supp. 439, 447 (E.D.N.Y. 1969)) (emphasis by the court). The citations omitted by the Stern court referred to Myzel v. Fields, 386 F.2d 718 (8th Cir. 1967), cert. denied, 390 U.S. 951 (1968); Lorenz v. Watson, 258 F. Supp. 724 (E.D. Pa. 1966); Hawkins v. Merrill, Lynch, Pierce, Fenner \& Beane, 85 F. Supp. 104 (W.D. Ark. 1949). 
Another example of the Stern court's imprecision appeared in its discussion of the standards utilized to prove the merits of an action. The court remarked:

What the plaintiff in this action must establish is that those persons whom he contends are controlling persons have actively participated in the operations of Bankshares and possessed actual control over the transaction in question. Once that is established the matters of knowledge and actual participation, which directly or indirectly induced the fraud, are matters for the defense. ${ }^{21}$

This passage essentially asserts that two elements must be demonstrated in order to establish controlling person status: the first is some amount of participation in the operations of the entity alleged to be "controlled"; the second is possession of actual control over the violative transaction.

Both of these elements are subject to criticism. The inclusion of a participation requirement is misguided because the need for a controlling person's participation in the violation ${ }^{92}$ relates to the liability issue instead of the status issue; the Stern court lost this distinction when it improperly adapted the Holloway language. Similarly, the actual control test is unnecessarily misleading. Taken literally, the phrase suggests that liability will only be imposed when the defendant affirmatively exercises control over the primary violator's actions. But when the opinion is closely scrutinized, it is apparent that the court intended to distinguish between the possession and exercise of actual control. As a result, the second prong of the Stern test in reality requires the defendant to possess the potential for involvement in, or control over, the transaction in question. The availability of a logical interpretation does not, however, alleviate the difficulty in separating status phase analysis of "actual control" and the determination of "actual involvement or participation" during litigation of the liability issue.

\section{Conceuston}

The controlling person provisions reflect Congress' desire to place responsibility for securities violations upon those persons who directed or influenced the violators. These laws were designed to cut through formal legal insulation and impose liability upon in-

91429 F. Supp. at 824 .

02 The Stern court's formulation may reflect the concern in Holloway that an outside director could be held liable for violations arising from matters which he or she had no knowledge of or control over. 
dividuals whose power and influence were believed to enable them to select and control potential violators of the Acts.

Where a principal-agent relationship exists, there is no need to invoke these provisions and extend their special defenses to alleged violators. ${ }^{93}$ Moreover, the controlling person provisions are probably best viewed as having been addressed to a special case of the "indirect violation" described in section 20(b) of the 1934 Act.94 Under this view, the demonstration of a control relationship would establish a prima facie violation of section $20(\mathrm{~b})$ through the use of intermediaries, and would shift the focus of analysis to the controlling person sections, where the burden is upon the defendant to establish the applicability of exculpatory language. By viewing controlling person liability as a subset of the general liability of those who accomplish violations through others, courts may gain a perspective on the provisions that will help prevent hasty findings of controlling person status and liability.

A finding of controlling person status has a dramatic effect upon a defendant in a securities action because he must thereafter shoulder the burden of establishing a defense. In recognition of this fact, courts should carefully scrutinize allegations of control and remove the controlling person sections from the context of agency. If it is remembered that the conceptual basis for imposing liability is to punish those who violate through others rather than to reinforce a pre-existing duty to supervise, much confusion in the status phase of controlling person analysis can be eliminated and better decisions produced.

With regard to the liability issue, it appears that when the cases applying the provisions to agency relationships are set aside, a requirement of an affirmative act in furtherance of the violation emerges as a condition for the requisite "inducement" under the 1934 Act provision. (One possible exception to this rule is the case of inaction intended to further an illegal scheme by delaying its discovery.) The need for this standard becomes increasingly evident when the "duty to supervise" rationale is properly rejected.

This Comment has argued that the complex nature of controlling person liability and the prevalence and severity of confusion in judicial analysis necessitate a clarification and reexamination of existing standards. Several steps can be taken to facilitate this process. First, the controlling person provisions should be removed from the agency context; they are not vehicles for the imposition of

93 See text accompanying notes 12-17 supra.

$94 \mathrm{Id}$. 
strict liability on principals and supervisors who cannot establish a reasonable defense; common law theories are available to accomplish this result. Second, the two issues of status and liability should be kept separate and distinct in both theory and application, despite the frequency of their intermingling in the case law to date, and the difficulty in identifying instances of their confusion. Third, a requirement of an affirmative act or a failure to act intended to further a violation should be acknowledged by courts interpreting section 20(a). Fourth, the "indirect violation" rationale of the controlling person provisions should be recognized and used as a guide to statutory interpretation. If it is agreed that these sections are designed to reach a special class of persons who violate the Acts through others, courts will be able to take a consistent and more accurate approach to the issues of controlling person status and liability. The greater predictability that will result from an effort to improve controlling person analysis will make more effective securities regulation possible. 